\title{
Cluster de Turismo e as Experiências do Estado de Minas Gerais na Formação de Circuitos Turísticos
}

\section{Tourism Cluster and the Experiences of the State of Minas Gerais in the Formation of Tourist Circuits}

\section{Cluster de Turismo y las Experiencias del Estado de Minas Gerais en la Formación de Circuitos Turísticos}

Jean Tavares ${ }^{1}$

\section{Resumo}

A criação de circuitos turísticos é importante para o desenvolvimento do turismo visto que, muitas vezes, municípios polos com um atrativo exponencial pode "absorver" toda a atenção do turista e não colaborar com o crescimento de municípios no seu entorno, que também possuem atrativos merecedores de serem visitados. Como a concepção de circuitos turísticos é complexa, o objetivo desse artigo é elaborar - baseado na literatura de cluster e nas experiências ocorridas no Estado de Minas Gerais - uma proposta para a formação de circuitos turísticos que possa ser usado dentro e fora do contexto acadêmico pelos agentes ligados ao setor e que contemple as principais funções da administração, a saber, o planejamento, a organização, a decisão e o controle. Além disso, essa "proposta" serve como um mecanismo de checagem para os circuitos em funcionamento. Sugere-se, para pesquisas futuras, testar esse guia em regiões turísticas para que se façam melhorias.

Palavras-chave: Cluster; Circuitos turísticos; Minas Gerais.

\begin{abstract}
The creation of tourist circuits is important for the development of tourism given that, often, a municipality with an exponential attractive can "absorb" all the attention of the tourist and not cooperate with the growth of municipalities in its surroundings, which also have attractive deserving of to be visited. As the formation of tourist circuits is complex, the aim was to develop - based on the cluster literature and in the experiences occurred at Minas Gerais - proposal to development of regional tourism through of the tourist circuits formation which can be used inside and outside the academic context, covering the main functions of management, namely planning , organizing, decision and control. In practice, this proposal may serve as a checking mechanism for the circuits already in operation. It is suggested, for future research, test this "manual" in tourist regions with the aim to make improvements.
\end{abstract}

Keywords: Cluster; Tourist circuits; Minas Gerais.

\footnotetext{
${ }^{1}$ Professor Adjunto IV do Departamento de Economia da PUC Minas. Doutor em Economia (Universidade Federal do Rio Grande do Sul). Pós-doutor em Economia do Turismo (Universidade Nova de Lisboa). Brasil. E-mail: jeanpucminas@uol.com.br
} 


\section{Resumen}

La creación de circuitos turísticos es importante para el desarrollo del turismo visto que los municipios polos a menudo con un atractivo exponencial puede "absorber" toda la atención de los turistas y no apoyar el crecimiento de los municipios de los alrededores, que también tienen atracciones digno de ser visitado. La medida que el diseño de los recorridos es complejo, el objetivo era desarrollar - en base a la literatura clúster y en las experiencias en Minas Gerais - una propuesta para el desarrollo del turismo regional a través de la creación de circuitos turísticos que se pueden utilizar dentro y fuera del contexto académico, que cubre las funciones principales de la gestión, es decir, la planificación, organización, decisión y control. En la práctica, esta " proposta " puede ejercer una función secundaria - para servir como un mecanismo de control para los circuitos operativos. Se sugiere, para la investigación futura, probar esta guía en las regiones turísticas por las mejoras decisiones.

Palabras-clave: Cluster; Circuitos turísticos; Minas Gerais.

\section{Introdução}

Em relação à literatura acerca dessa temática, é preciso antes fazer uma distinção importante. Embora os circuitos turísticos, em muitos trabalhos, sejam tratados como "itinerários ou roteiros" localizados em um espaço geográfico mais limitado - normalmente um município neste artigo os circuitos turísticos são considerados como um agrupamento de municípios possuidores de atrativos turísticos, os quais compõem um "destino único" em um espaço geográfico mais amplo.

Dentre os autores que pesquisam os circuitos turísticos de forma mais próxima a essa concepção, destacam-se Bolson (2004), Carvalho (2007), Emmendoerfer et al. (2007), Domingos e Ribeiro (2008), Gomes et al. (2008), Ventura (2010), Ferreira (2011), Milheiro et al. (2011). Porém, grande parte dos destinos turísticos ou com potencial turístico localizam-se em regiões que não possuem os melhores indicadores econômicos e sociais, seja em virtude da excessiva dependência de transferências governamentais ou em razão do incipiente desenvolvimento do comércio e da indústria. Além disso, em muitas delas, os atrativos são espacialmente dispersos, o que pode dificultar a mobilidade e a permanência dos turistas.

Uma saída para essa situação seria o setor público e/ou privado tratarem essas regiões como uma "única região" ou como um "único destino turístico", transformando atrativos em produtos turísticos, formando assim, os circuitos turísticos. Segundo Tavares et al. (2010, p.4) "uma 
determinada atratividade local pode ser insuficiente para atração e, principalmente, retenção do turista. Porém, várias atratividades - localizadas em um conjunto de regiões contíguas, por exemplo - poderiam ser capazes de fazê-lo".

Em relação ao Estado de Minas Gerais, de acordo com Oliveira e Januário (2007, p.3), “como a Constituição Federal não permite a intervenção do Estado diretamente nos municípios (...) optou-se por uma solução regionalizada, com destaque para os Circuitos Turísticos e a Estrada Real”. Para Santos (2004, p.29), o CT “compreende um conjunto de municípios com relativa proximidade em determinada área geográfica, caracterizado pela predominância de certos elementos da cultura, da história e da natureza, com possibilidades de atrair e seduzir turistas". Porém, nesse Estado, diversos circuitos turísticos têm enfrentado dificuldades para a sua consolidação (DOMINGOS e RIBEIRO, 2008; GOMES et al. 2008), pois, embora a justificativa para a sua formação seja plausível, sua concepção é complexa. As diferenças entre os municípios (singularidade do atrativo, "peso" do turismo na economia, importância política, etc.) podem ser tornar mais difícil a formação e a consolidação de um circuito turístico. Além disso, outros aspectos são igualmente importantes para a consolidação de um circuito, tais como o seu nome, a quantidade de municípios que possui, a tipologia do turismo, a percepção de sua imagem/identidade e a sua sustentabilidade financeira.

Portanto, o objetivo desse artigo é elaborar - baseado na literatura de cluster e nas experiências ocorridas no Estado de Minas Gerais - uma proposta para a formação de circuitos turísticos que possa ser usado dentro e fora do contexto acadêmico pelos agentes ligados ao setor e que contemple as principais funções da administração, a saber, o planejamento, a organização, a decisão e o controle. Essa proposta serve também como check-list para os circuitos em funcionamento.

\section{Revisão da Literatura}

\subsection{Cluster turístico e circuito turístico}

Embora a literatura relativa aos clusters já esteja consolidada, sua proximidade conceitual com os circuitos turísticos ainda carece de mais investigação. Para Albagli e Brito (2003), cluster seria "agrupamentos territoriais de agentes que desenvolvem ações similares". 
Para Veiga (1999, p.1306), citado por Silva (2004), este seria uma "concentração geograficamente delimitada de negócios independentes que se comunicam, dialogam e agem para partilha tanto de oportunidades quanto de ameaças, gerando novos conhecimentos, concorrência inovadora, chances de cooperação (...)”. Segundo Britto (2000), mencionado por Santos (2003), a característica básica do cluster "é o agrupamento de agentes não similares, mas que apresentam competências complementares, o que reforça a interdependência entre eles e a necessidade de alguma forma de coordenação coletiva no nível do arranjo”.

Por fim, para Toledo e Silva (2004, p. 8), a condição fundamental para se formar um cluster a partir de um espaço geográfico seria "a cooperação, tanto em termos de cultura voltada à cooperação, quanto em termos de estrutura, caracterizada pela existência de entidades específicas que agreguem diversos interessados e permitam a formulação e implementação de estratégias cooperativas".

Pelas definições de cluster acima, é possível aplicá-lo ao turismo de forma direta. O termo "agrupamentos territoriais" é inerente à origem e à ocorrência dessa atividade, principalmente se for usado o conceito de circuito turístico não usual (TAVARES et al. 2010), até porque, para Cunha e Cunha (2005, p.3), "a complementaridade e interdependência dos componentes do conglomerado turístico ocorrem através da organização dos atores locais (...)" - e estes são elementos presentes no conceito de cluster.

Para Beni (2003, p.74), “cluster turístico é o conjunto de ações com destacado diferencial turístico, concentrado num espaço geográfico delimitado dotado de equipamentos e serviços de qualidade, de eficiência, de coesão social e política, de articulação da cadeia produtiva e de cultura associativa, e com excelência gerencial em redes de empresas que geram vantagens estratégicas comparativas e competitivas".

Por essa definição, seria mesmo difícil encontrar um cluster turístico, até porque as exigências de "coesão social e política" e "excelência gerencial em redes de empresas" são realidades atípicas na atividade turística, que é fragmentada, com estágios diferentes de desenvolvimento. Em Portugal, talvez a região do Algarve possa se aproximar dessa definição de cluster turístico de Beni (2003), embora com ressalvas e, no Brasil, a região da serra gaúcha - mais precisamente Gramado e Canela - certamente se aproxima nesse amplo conceito de cluster (MICHELON, 2003). 
Em princípio, a definição mais próxima do conceito de circuito turístico mencionado anteriormente é o de Gutiérrez e Bordas (1993), para os quais os clusters "compreendem agrupamentos de vários atrativos turísticos concentrados em uma região geográfica, com infraestrutura compatível, equipamentos, serviços receptivos e órgãos e agentes turísticos coordenados para oferecer um produto turístico integrado e diferenciado".

Observa-se, portanto, que o agrupamento formal de espaços turísticos localizados próximos uns aos outros pode, em primeira instância, se tornar um cluster e agir em rede para responder às dificuldades próprias do turismo, buscando soluções em conjunto. Mas quais seriam os parâmetros para se estabelecer um agrupamento de espaços turísticos? De acordo com Ivars (2003), a região deve ter um conjunto de características culturais, físicas e sociais que gerem uma identidade regional; b) deve haver uma adequada infraestrutura turística e oferta de serviços para permitir o desenvolvimento turístico e satisfazer as necessidades dos turistas; c) (...) deve ser maior que um destino ou uma única atração; d) (...) deve possuir os atrativos suficientes para atrair turistas ou potencialmente; e) (...) tem que ter a capacidade de criar uma agência de desenvolvimento e ações promocionais para fortalecer o desenvolvimento turístico; f) (...) deve ser acessível para uma massa

populacional importante.

Pelas condições acima descritas, o conceito de circuito turístico mencionado anteriormente aproxima-se, sob vários aspectos, da formação de um cluster. Por fim, conforme Cunha e Cunha (2005, p.2), o conceito de cluster seria adequado às características específicas de turismo, pois “o produto turístico interage com a base local (física e atores sociais), permite ações conjuntas de negócios inter-relacionados, com grande potencial para criação de conglomerados". Porém, a "oferta de um produto integrado e diferenciado", defendida por Gutiérrez e Bordas (1993), raramente é encontrada nas regiões turísticas ao redor do mundo.

Embora a formação de cluster em turismo possa resultar na sua dinamização por meio de mais turistas na região, no tempo de sua estadia e nos gastos realizados, para Amato Neto (1999, p.53), citado por Silva (2004, p.213), a combinação de concentração territorial e geográfica pelo cluster pode fragilizar a região onde se instala mediante "as mudanças de paradigmas nos produtos e nas tecnologias empregadas. Esse é o principal argumento contra a concentração de clusters". 
Porém, no turismo, essa possibilidade parece ser remota, pois o turismo baseia-se "em ativos (incluindo práticas e relações) que não estão disponíveis em outros lugares e que não podem ser facilmente ou rapidamente criadas ou imitadas em lugares que não as têm" (CASSIOLATO e SZAPIRO, 2003, p. 40) citados por Silva (2004, p.213).

Para Silva (2004), “os clusters têm maior capacidade de sobreviver aos choques e à instabilidade do meio ambiente do que as empresas isoladas, em virtude da ação em conjunto e de sua alta capacidade de autoreestruturação (...) e à própria forma organizacional em rede". Mesmo se superada essa questão e apresentando aspectos similares à formação de cluster, algumas características da atividade turística podem dificultar a consolidação do cluster do sector. Dentre estas, estão a dispersão da oferta turística, ou seja, inexistência de produtos planejados e integrados para o turista, a falta de cooperação entre os agentes públicos e privados, a ausência de pesquisas regulares e tratamento de dados acerca da atividade turística e dependência excessiva do sector público no planeamento de longo prazo, com o complicador adicional de uma possível interrupção de um projeto político a cada eleição (TOLEDO e SILVA, 2004; VICENTIM et al. 2006);

De qualquer forma, um circuito turístico similar ao conceito de cluster pode gerar vários benefícios que, individualmente, ou não seriam alcançados ou seriam obtidos em menor grau, tais como a) maior poder financeiro na promoção do destino em níveis nacionais e internacionais; b) maior poder de barganha junto às instituições públicas; c) condições mais favoráveis para a realização de pesquisas de demanda turística; d) organização de um fórum próprio para troca de experiências com periodicidade pré-estabelecida e e) mais credibilidade junto a organismos de financiamento (TOLEDO e SILVA, 2004, p.8).

Outras vantagens também podem ser consideradas, como, por exemplo, a oferta de produtos integrados e diversificados e a definição da imagem como um todo e para todos os agentes envolvidos, além de, segundo Cunha e Cunha (2005), "combater as disparidades regionais e as desigualdades sociais".

Baseado nestas vantagens e características, Martins e Sicsú (2005) entendem que, para se identificar um cluster turístico, é preciso observar "a existência de interesses turísticos (atrativos turísticos, infraestrutura e cultura para a recepção dos turistas), a iniciativa empresarial local com apoio do poder público, ações coletivas e ambiente de cooperação e competição e da presença de uma gestão estratégica". 
Por fim, observa-se uma diferença significativa entre os conceitos de cluster e circuito turístico. O primeiro define a cooperação como a base de sustentação do cluster, sendo a competição fortemente incentivada e a rivalidade condição necessária para a sua continuidade (CUNHA e CUNHA, 2005). Já o último coloca a cooperação em um patamar ainda mais elevado. A competição pode ocorrer entre empresas do setor mas, entre as regiões envolvidas no conceito de uma "única região turística", a cooperação torna-se condição necessária para a sua sobrevivência, questão que será mais discutida adiante.

\subsection{A experiência dos circuitos turísticos em Minas Gerais}

O significado da expressão "circuitos turísticos" pode variar de um país para o outro ou entre diferentes regiões de um mesmo país (BOLSON, 2004; BERCIAL e TIMÓN, 2005; CASTRO, 2007; SANTOS, 2007; GOMES et al. 2006; BRIDA et al. 2008; DOMINGOS e RIBEIRO, 2008; GOMES et al. 2008).

Em princípio, o conceito mais usual de circuito turístico é o de um "um conjunto de pontos turísticos a serem percorridos em um único destino", até porque dificilmente um turista viaja para apenas uma localidade ou é atraído por somente um ou dois atrativos turísticos. Quanto a isto, Santos et al. (2010, p.1) afirma que, "apesar de que as viagens multidestinos representam uma parcela significativa do total de viagens turísticas em muitos casos, a maior parte dos estudos sobre a demanda turística assume que as viagens têm um destino único".

Com o desenvolvimento progressivo da tecnologia, o acesso à informação tornou-se mais amplo. Antes mesmo de viajar, o turista pode verificar os atrativos turísticos em um raio considerável onde pretende se hospedar, visitá-los e ainda sim retornar no mesmo dia. Ao mesmo tempo, a competição entre os destinos turísticos tornou-se intensa, dificultando o gerenciamento de destinos menos conhecidos para o seu desenvolvimento e sua promoção.

Esse cenário reflete bem o conceito de circuito turístico desse trabalho - um conjunto de municípios político-administrativos possuidores de diversos atrativos turísticos espacialmente diversos e, geralmente, localizados próximos uns dos outros, o qual atua de forma conjunta na organização, gestão, promoção e comercialização do turismo.

A ideia incorporada nesse conceito é que um município com poucos atrativos e localizado próximo a um município dotado de mais infraestrutura (tendo mais atrativos turísticos ou não) pode não ter condições de atrair, sozinho, os turistas. Mas se este município fizer parte de um 
conjunto de outros municípios com caraterísticas semelhantes talvez tenham possibilidade de fazer parte de um destino turístico "mais amplo", denominado de circuito turístico.

Para Castro (2007, p.22), a criação de circuito turístico deu-se em virtude da percepção de que “(...) a proximidade entre determinados municípios, considerando suas afinidades ou diferenças, significava novas possibilidades em relação ao desenvolvimento turístico".

De acordo com Oliveira e Santos (2006, p.333), a organização de circuitos ou rotas turísticas e deve "à necessidade de se obter vantagens competitivas, onde a disponibilidade dos produtos e serviços turísticos deve se complementar", podendo, assim, aumentar a possibilidade de atendimento pleno às expetativas dos turistas. Teixeira et al. (2006) também afirmam que municípios pequenos podem se aliar ao município mais desenvolvido e próximo geograficamente para, juntos, desenvolver a atividade turística.

De acordo com Emmendoerfer et al. (2009, p.398), existem quatro razões para a formação de um circuito turístico, a saber: a) descentralização da gestão do turismo devido a grande extensão territorial do Estado por meio da criação de circuitos como associações não governamentais; b) a certificação, o reconhecimento e o apoio do poder público a estas associações; c) por uma nova forma de ofertar outros tipos de turismo que não os tradicionais (cultural e termal) da região; d) pelo planeamento em conjunto com a sociedade e não apenas realizado pelo poder público.

Em Minas Gerais, o governo reconheceu e certificou 46 circuitos turísticos, seguindo a Secretaria de Turismo do Estado (SETUR, 2015). Antes, porém, orientou, mesmo que de forma resumida, as ações necessárias para a formação (e posterior reconhecimento) desses circuitos, a saber: a) Identificar os municípios que tenham alguma afinidade turística ou que se complementam turisticamente, que estejam num raio aproximado de $100 \mathrm{~km}$; b) Mobilizar representantes do Poder Público, iniciativa privada e comunidade de cada município interessado; c) Realizar reunião de integração com a participação dos técnicos da SETUR; d) Definir, através da identidade comum regional dos municípios participantes, o nome do Circuito Turístico; e) Definir o tipo de entidade gestora: Associação, Agência de Desenvolvimento etc.; f) Elaborar um Estatuto/ Regimento Interno (EMMENDOERFER et al. 2011).

Dessa forma, além de competir com as demais regiões turísticas do Brasil, a proposta de criação de circuitos turísticos para a promoção do desenvolvimento desse setor tem intensificado a competição entre as próprias regiões de Minas Gerais. Esse cenário exige, portanto, excelência 
em termos de governança - que seria o uso de "padrões de articulação e cooperação entre atores sociais e políticos e arranjos institucionais que coordenam e regulam transações dentro e através das fronteiras do sistema econômico", Santos (1997, p. 341) - e o claro entendimento do processo de regionalização da atividade turística por parte dos gestores desses circuitos.

Quanto a isso, González e Mendieta (2009, p. 126) afirmam que "um destino competitivo é aquele que satisfaz a demanda e mantém um fluxo de comunicação e colaboração entre os diversos atores que intervém no destino: empresários locais, população e governo".

Araújo (2009, p. 141), em estudo realizado no Circuito Turístico das Águas, observou que “(...) os empresários se opõem politicamente ao poder público municipal, o que inviabiliza qualquer tentativa de se estabelecer uma parceria público-privada. Existe, também, uma forte competição entre as prefeituras também por questões partidárias".

Domingos e Ribeiro (2008, p. 3), em pesquisa realizada no Circuito Grutas e Mar de Minas, verificaram que “(...) apenas a vontade política, a proximidade dos municípios e a existência de atrativos turísticos não são suficientes para transformar uma região geográfica em uma região turística”.

Tavares et al. (2010) analisaram as experiências em seis circuitos turísticos de Minas Gerais, a saber, Serra Geral do Norte de Minas, Lago de Irapé, das Grutas e Mar de Minas, Circuito Verde Trilha dos Bandeirantes, Nascentes das Gerais e Terras Altas da Mantiqueira e verificaram que

\begin{abstract}
"a escolha pelos municípios polos destes circuitos apresenta vários problemas, tanto em termos de infraestrutura suficiente para "receber e distribuir" os turistas para os demais municípios quanto em termos de localização, visto que os turistas poderiam ser "capturados" por municípios importantes e adjacentes. Em relação às condições de acesso, os CT's analisados possuem, em geral, boa disponibilidade de vias. Esta, porém, diminui à medida que os municípios se afastam em direção ao norte de Minas e aumentam ao se aproximarem da capital ou dos Estados do Rio de Janeiro e São Paulo. Por fim, no que se refere aos atrativos turísticos, percebe-se que muitos CT's devem competir de forma intra estadual em Minas Gerais dada a semelhança entre seus atrativos, o que pode significar, por um lado, maior busca pelo aprimoramento dos serviços oferecidos".
\end{abstract}

Tavares e Vieira Junior (2010), em estudo realizado no Circuito Turístico Terras Altas da Mantiqueira, em Minas Gerais, verificaram que os principais problemas enfrentados eram a 
inadequação da imagem do circuito, os entraves políticos e a falta de recursos financeiros, bem como a existência do sistema all-inclusive na rede hoteleira.

Em pesquisa realizada por Gomes et al (2008, p.14) junto aos gestores de CT's de Minas Gerais, os autores verificaram que "a falta de infraestrutura básica, a falta de conhecimento sobre turismo por parte da população local e a escassez de mão de obra qualificada são fatores que dificultam a consolidação do CT”, dentre outros.

Tavares et al. (2011), em pesquisa realizada no Circuito Turístico Montanhas Mágicas de Minas, no Sul do Estado, concluíram que o mesmo "tem uma difícil missão para garantir seu desenvolvimento e até mesmo sua própria sobrevivência", em razão da proximidade e consequente competição com os Circuitos Turísticos Terras Altas da Mantiqueira e das Águas.

Mas à medida que a atividade turística começa a ser vista como via para dinamizar uma região sob a forma de circuito turístico, entende-se a necessidade de se fazer uma avaliação ampla e detalhada de todos os elementos que o compõe, tais como a escolha do número de participantes, a definição da imagem, a escolha do nome e do município polo, a tipologia do turismo, condições de acesso, sua sustentabilidade financeira, sua relação com a inovação, conforme apresentado a seguir.

\section{Elementos formadores de um circuito turístico}

a) Número de municípios participantes

Embora exista uma ténue diferença entre "pequena" e "grande" em termos de formação de circuitos turísticos, é possível fazer algumas considerações a respeito. Por exemplo, um circuito "pequeno" é aquele que consiga atrair mas não reter os turistas por um tempo superior a 2 ou 3 dias, em média. Já um circuito "grande" pode ser aquele que, mesmo de forma involuntária, seja possível praticar vários tipos de turismo, dificultando a criação de um nome e/ou de uma marcar. Também enquadrado nesta "nomenclatura" seria o circuito em que o turista precisasse de muito tempo para conhecê-lo, exigindo duas ou mais viagens à região ou mais de 1 (uma) semana de estadia.

Em relação ao número de municípios que deve compor um circuito turístico, Gomes et al. (2006, p.327) afirmam que "circuitos muito grandes (...) não têm conseguido avançar no seu processo de organização". Em Minas Gerais, a média de circuitos é de 10,3 (varia de 5 a 20 municípios), conforme informações da SETUR (2011). 
Certamente não há um número específico de municípios que devam fazer parte de um circuito turístico, mas estas considerações devem ser feitas antes de sua definição. A partir daí, deve-se verificar a tipologia de turismo predominante nos municípios escolhidos para a formação do circuito, conforme será discutido a seguir.

b) Tipologia do turismo

Além da quantidade de municípios que devem fazer parte de um circuito turístico, é preciso fazer um levantamento de suas condições em todos os aspectos, tais como atrativos turísticos, meios de hospedagem, restaurantes, locadoras de automóveis, entretenimento, dentre outros, vias de acesso, agências bancárias, hospitais, etc. Esta é a chamada fase de inventário turístico (MILHEIRO et al. 2010).

Em seguida, enquadra-se o espaço turístico regional, classificando-o quanto a sua tipologia turismo gastronômico, cultural, de sol e praia, de aventura, dentre outros. Esta etapa de estruturação de um circuito turístico é fundamental, pois ao mesmo tempo em que cada vez mais os destinos turísticos competem entre si, a sua definição implica na formação adequada da imagem do circuito.

Por outro lado, englobar todos os tipos de turismo existentes pode ser uma medida ineficaz para a atração de turistas. Uma região que afirma permitir a prática de turismo náutico, de natureza, de sol e mar, gastronômico, paisagístico, negócios e turismo esportivo, dentre outros, pode passar uma imagem tão ampla que se torna imprecisa quanto a sua tipologia.

Em relação à tipologia de um circuito, um investimento para a construção/reparação de uma ferrovia para que possa ter um trem de passeio entre pontos turísticos, a instalação de um teleférico ou até mesmo a instalação de um parque temático poderiam influenciar na sua configuração ou até mesmo em sua identidade - nesse último caso, o perfil dos turistas no circuito possivelmente seria modificado.

c) Imagem/ Identidade visual

A formação da imagem adequada para um destino turístico tem atraído a atenção de vários pesquisadores (NETO et al. 2008; SANTILLA, 2010), pois muitos turistas em potencial irão decidir se deslocam ou não para um destino a partir da imagem que o turista tem a respeito do mesmo. 
Cunha e Ferreira (2008, p. 3), defendem que "uma imagem adequada deve corresponder à realidade, ter credibilidade, ser simples e diferenciada e ter um símbolo visual". Além disso, os circuitos devem ter afinidades, aumentando as chances de cooperação.

Em relação ao símbolo ou identidade visual, esta pode ser representada por um produto específico ou singular, de conhecida reputação, por um clima muito caraterístico, uma razão inequívoca que justifica a presença de turistas, uma cultura muito particular, relevo ou hidrografia muito propício a diversas atividades ou bem definidos.

O caso do Circuito Turístico do Ouro, localizado na região central de Minas Gerais, (figura 4) atende apenas parcialmente a esse requisito acima. Embora tenha a palavra "ouro" em sua denominação, ressalta-se que a logomarca do circuito parece não estar sintonizada a essa denominação. Espera-se, portanto, que a sua identidade visual esteja relacionada ao fato de que a região tenha sido na época do Brasil império, a mais rica em ouro do país.

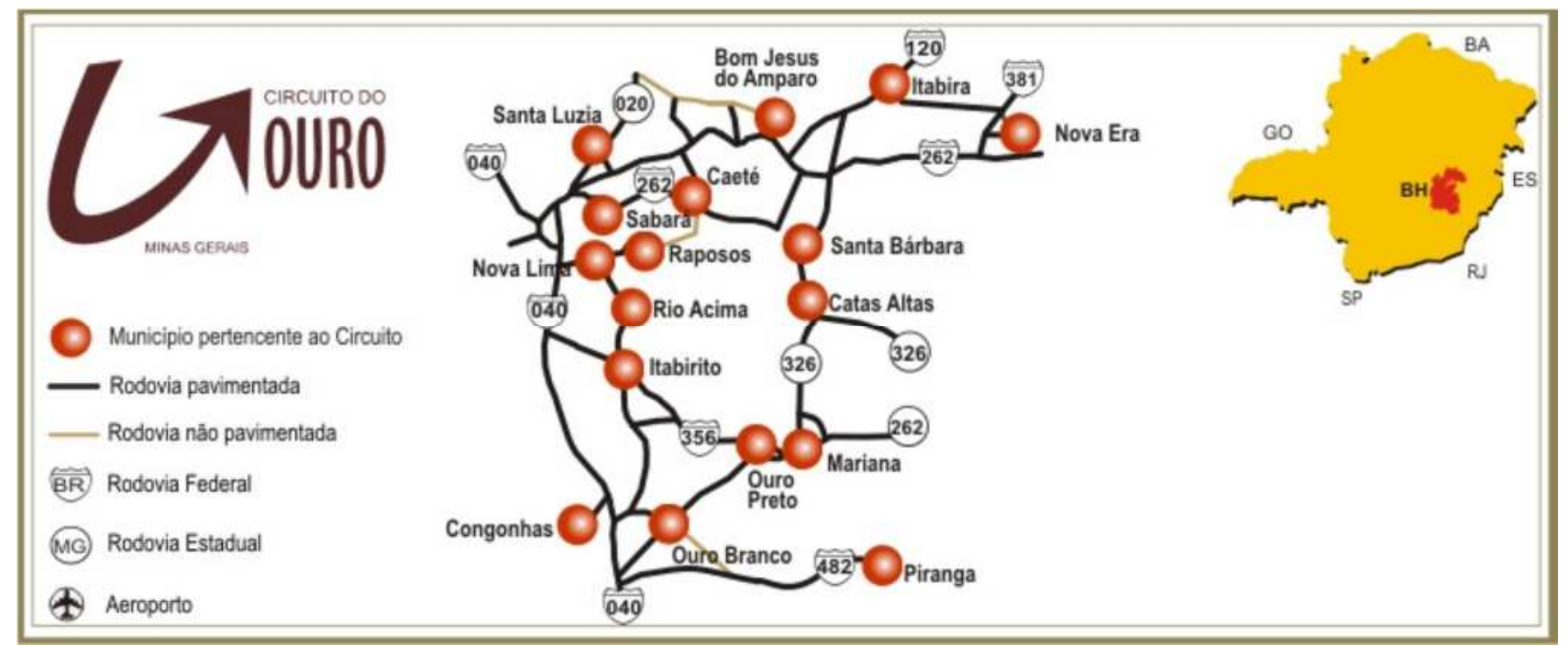

Fonte: SETUR, 2015.

Figura 1- Circuito Turístico do Ouro

A definição da imagem e da identidade visual de um circuito turístico é mais importante ainda quando não se trata de turismo de "sol e praia", visto que a maioria da população mundial não vive no litoral e usualmente espera o verão para aproveitar esse tipo de turismo.

Embora pareça fácil desenvolver uma imagem ou a identidade regional de um circuito turístico, Silva et al. (2012), em pesquisas realizada em alguns circuitos de Minas Gerais (Brasil), 
observaram que cerca de $70 \%$ das imagens apresentavam apenas afinidades culturais e ambientais.

A questão da imagem merece mais algumas considerações, até porque a imagem de destino é essencial para a escolha de um destino turístico. Esta deve ser verificada ainda nos estágios iniciais de desenvolvimento do circuito turístico a fim de que seus responsáveis possam agir de acordo com a percepção dos turistas atuais, embora seja uma tarefa muito difícil mudar a imagem de um destino, caso seja necessário ou desejável (LEISEN, 2001).

Por fim, uma vez discutida a importância de se formar a imagem e identidade visual de um circuito como uma "marca" que irá representar não apenas produtos e serviços como também a experiência que pode ser vivida ali (SANTOS, 2004, p.26), deve-se definir o nome do circuito, de acordo com a discussão a seguir.

d) Denominação

Uma vez definida a imagem que o circuito que pretende ter (ou que eventualmente já possua), passa-se a definição do nome que deverá ter. Para Teixeira, Vicentim e Aguiar (2006), é a partir da definição da identidade regional em comum que se deve nomear o CT, o qual deve trazer ao imaginário do turista o que ele efetivamente pode encontrar ao ir ao encontro deste circuito.

É importante ressaltar que circuitos turísticos que estão muito ou unicamente associados a "imagens mais rígidas" podem estar em desvantagem em relação aqueles que podem “diversifica-las", como ocorre, por exemplo, quando o seu nome está bastante restrito aos seus elementos naturais, podendo transmitir ao turista a ideia de que não há novidades ou alterações significativas na região.

Embora isso não seja uma questão grave, em um mundo em que as pessoas procuram novidades, um reduzido poder de atração da denominação do circuito turístico pode dificultar o crescimento do turismo regional, exigindo esforços maiores e mais dispendiosos em termos de marketing.

Nesse caso, parece haver duas "soluções" que poderão servir tanto para a denominação do circuito quanto para sua imagem. A primeira possível solução seria a realização de eventos, tornando "mais dinâmica" a realidade do circuito, como parece ser o caso do tradicional evento "Natal Luz", que ocorre em Gramado (RS), a Festa Literária Internacional de Paraty (RJ) e também da renomada Mostra de Cinema em Tiradentes (MG). Segundo Carneiro e Fontes 
(1997, p. 71), “a sofisticação vem permitindo a organização de programações - eventos - que estão motivando e orientando o consumo de determinada localidade - bens e serviços - e diminuindo a ociosidade característica da baixa estação; com isso promovendo melhor aproveitamento do produto turístico".

A segunda possível solução seria instituir nomes para o circuito em determinados períodos ou épocas do ano. Por exemplo, no inverno, determinada paisagem pode se modificar de tal forma que talvez seja interessante "mudar" o nome do circuito para essa época específica. Em circuitos conhecidos por terem baixas temperaturas (como os do sul de Minas, por exemplo), a denominação do circuito poderia mudar - temporariamente - para algo associado ao verão nos meses de clima quente. Essa "renomeação do circuito" pode contribuir para estimular o turismo regional.

Por fim, os nomes dos circuitos turísticos devem seguir as realidades locais ou que fazem parte do imaginário acerca do que é o produto turístico daquela região - existência de serras, boa gastronomia, riqueza mineral e arqueológica, produtos agrícolas, recursos hídricos, costumes, paisagens, dentre outros.

e) Município polo

É evidente que um município polo deve ser responsável em receber boa parte da demanda turística de um circuito, ou seja, por acolher "o contingente de indivíduos dispostos a se deslocar de seu local de origem ou ponto emissivo, com vistas a "consumir" um determinado "produto turístico", localizado em um ponto receptivo" (DINIZ e VERSIANI, 2006, p. 96). Porém, os atrativos turísticos não precisam, necessariamente, estarem localizados no município polo.

A escolha do município polo (ou de referência) do circuito é fundamental, pois nele o turista deve estabelecer sua "base", hospedar-se, conhecer os atrativos turísticos localizados nos municípios próximos durante o dia e retornar - questões relacionadas à oferta turística.

Segundo Andrade (1999, p. 83),

"a oferta turística é formada pelos atrativos turísticos originais (atrativos naturais, históricos e culturais da região) e não originais (compostas pelas manifestações culturais organizadas e realizações técnico-científicas), equipamentos e serviços de apoio (setor de alimentação, hospedagem e transporte, serviços de informações turísticas, etc.) e infraestrutura" (Moretto, 1996; Beni, 1997). 
Portanto, de acordo com Diniz e Versiani (2006, p. 96), "uma oferta turística ou produto turístico é o resultado de uma união de elementos, capazes de atrair e manter um público de visitantes em um local específico, durante um determinado período de tempo".

O município polo deve ter, preferencialmente, mais infraestrutura que os demais, principalmente em termos de facilidades de acesso, sinalização adequada, sistemas bancário e de saúde e transporte público, visto que segundo Tavares et al. (2010), o município polo deverá "prestar o suporte necessário em termos de infraestrutura para o "acolhimento e distribuição" dos turistas do circuito turístico (...)”. Ainda que a demanda turística

Além disso, o município polo deve se localizar num ponto estratégico do circuito turístico e, se possível, próximo ou até mesmo equidistante de todos os demais municípios integrantes do circuito. A importância da localização tem respaldo na própria concepção de circuito turístico apresentada anteriormente, a qual orienta que o deslocamento até os atrativos turísticos e o retorno até o município de referência seja em menos de 24 horas. Caso contrário, se o município polo porventura escolhido ficar muito distante de todas as demais regiões do circuito, estão poderão receber a influência de outro município polo contíguo e ser "capturado", ou seja, os turistas e até mesmo a sua população podem preferir serem assistidos por um em detrimento do outro.

Outra observação importante no momento da escolha do município polo é em relação ao "peso" do turismo na economia. Isso pode ser verificado pelo número de empregados ligados ao setor em termos percentuais ou arrecadação do setor público, por exemplo. Se o "peso" for do setor for grande demais, certamente haverá uma liderança desproporcional e se for pequeno demais o turismo poderá ser relegado a segundo plano.

f) Material de apoio e divulgação

Em turismo, a existência de material de apoio e divulgação para a promoção da região turística é indispensável. O material pode ser de várias formas, tais como prospectos, mapas, roteiros, guias, dentre outros, além de divulgação nos diversos meios eletrônicos atuais.

Com a utilização de um Sistema de Informação Geográfica (SIG), podem ser elaborados os itinerários turísticos no conceito de circuito, dado que este considera a possibilidade do turista fixar-se em um dos seus municípios - geralmente com maior infraestrutura - e poder deslocarse no menor tempo possível para os municípios próximos. 
Além disso, o uso do SIG pode evitar situações inadequadas nos circuitos em relação às delimitações dos atrativos. Por exemplo, segundo Silva et al. (2012), os municípios integrantes "possuem" atrativos turísticos localizados no município contíguo.

Por fim, a criação de caminhos mínimos o reconhecimento da região alvo de estudo deve ser feito por meio de dados cartográficos existentes para, em seguida, se fazer a pesquisa, coleta e a compilação desses dados. Depois, poderão ser feitas visitas de campo para o georreferenciamento de locais que ainda não possuam bases cartográficas para, então, pesquisar e identificar os atrativos turísticos existentes (AMARAL e SILVA, 2009).

Simultaneamente, o setor de marketing deve analisar quais os mercados e plataformas irão receber o material produzido, o que pode ser facilitado por pesquisas das tendências do turismo e, principalmente, por meio da identificação das principais regiões emissoras de turistas em termos nacionais regionais. Certamente que profissionais da computação poderão contribuir neste aspecto.

Um dos lugares físicos que receberão todo o material de apoio e divulgação é o Ponto ou Centro de Informações Turísticas (CIT). Sua importância, estrutura e funcionamento serão discutidos a seguir.

g) Centro de Informações Turísticas (CIT)

Um CIT serve como ligação ente turistas e destinos (CRASE e JACKSON, 2000; HWANG e LI, 2008; MEI et al. 2008), tal que existe uma correlação significante e positiva entre a disponibilidade de informação e o aumento no gasto diário de turistas (TIERNEY, 1993; TYRRELL e JOHNSTON, 2003) e também uma influência positiva sobre o tempo de estadia no destino (FESENMAIER, 1994).

Apesar da maioria dos turistas terem acesso à internet, novas demandas podem surgir quando eles chegam aos destinos (GOHR et al. 2009), as quais poderão ser atendidas apenas por residentes - lugares mais seguros para caminhar, atalhos, dicas mais interessantes e restritas, mudanças recentes de estabelecimentos comerciais, entre outras informações disponíveis somente pelo CIT por meio de seus funcionários. Além disso, um CIT pode contribuir para aumentar a visita em atrativos turísticos previamente não escolhidos pelos turistas (HWANG e FESENMAIER, 2011).

Um CIT deve ter à disposição dos turistas informações gerais (guias turísticos e de compras, mapas da cidade e dos pontos turísticos), alguns serviços como, por exemplo, telefone público 
e acesso à internet grátis, bem como infraestrutura (água potável, banheiro (mesmo que anexo à instalação), fraldário e, se possível, um caixa eletrônico. Além disso, o CIT deve estar estrategicamente localizado em terminais de passageiros (portos, aeroportos, rodoviárias), mercados, pórticos, galerias, espaço de convenções, próximo aos mais importantes atrativos turísticos ou em praças públicas.

Embora não seja sua função principal, o CIT pode ser um local para a venda de produtos locais (artesanatos, lembranças e souvenirs), desde que haja espaço físico para tal, não prejudicando o exercício da sua razão de ser. Quanto a essa questão, a entidade gestora pode dar preferência para recomendar as empresas associadas ao circuito turístico, embora distribua material contendo todas as empresas da região. Nesse caso, a recomendação ocorre quando, em um atendimento personalizado, o turista solicita ao funcionário alguma recomendação de restaurante ou hospedagem, por exemplo.

Sheldon (1993) afirma que um CIT deve repassar uma informação precisa para se tornarem confiáveis e reiterar sua utilidade para os turistas. Porém, é comum encontrar CIT's que contribuem de forma negativa para o turismo na região, sendo um dos motivos, segundo Castelli (2001) citado por Lucca Filho (2005, p.52) a falta de preparo ou de motivação de seus funcionários, fazendo com que "na prática, muitos postos de informações são verdadeiros postos antimarketing. Na maior parte das vezes, isto se deve aos baixos salários pagos, levando ao emprego pessoas despreparadas".

h) Condições de acesso e sinalização turística

As condições de acesso e a sinalização turística são muito importantes para o desenvolvimento de um circuito turístico, sob pena do mesmo restringir-se ao município polo.

A sinalização turística é um “(...) conjunto utilizado para informar os usuários sobre a existência de atrativos turísticos e de outros referenciais, sobre os melhores percursos de acesso e, ao longo destes, à distância a ser percorrida para se chegar ao local pretendido" (EMBRATUR, IPHAN, DENATRAN, 2001, p.20).

A importância dessas variáveis é descrita por Santos (2004, p. 29), segundo o qual "para ocorrer a (...) integração regional entre os municípios de um mesmo circuito, vias de acesso compatíveis são fundamentais à complementaridade entre os atrativos, os meios de transporte, os equipamentos e os serviços e para o fortalecimento da cadeia produtiva (...)”. 
Já a sinalização é um aspecto que contribui para a satisfação do turista e, portanto, para o próprio turismo. Como qualquer pessoa, o turista não quer se sentir desorientado e nem ter perdido tempo e/ou dinheiro com deslocamento errado, diminuindo a qualidade de sua estadia (NOGUEIRA, 2012).

Portanto, "a sinalização é um elemento de valorização do lugar, devendo ser adequadamente integrada ao planejamento de desenvolvimento do turismo em busca da otimização, da qualidade e da melhoria dos produtos/serviços ofertados aos habitantes do lugar e aos turistas" (SOUZA, 2006, p.136).

Na sinalização, os elementos como a tipografia, pictograma, localização, tamanho, forma e tamanho são os principais balizadores desse mecanismo de informação e orientação. Aspectos como o tamanho inadequado das palavras/letras e espaçamento insuficiente (tipografia), figuras e ilustrações não-oficiais ou mal elaboradas (pictogramas) prejudicam a consolidação da imagem de um circuito turístico.

Por fim, "as informações contidas na sinalização turística permitem transmitir características sobre o local e de seus atrativos, possibilitando o deslocamento e por consequência o conhecimento maior da região visitada. Além disso, propicia ao destino turístico atrair mais investimentos e fluxo de turistas" (SILVA e MELO, 2012, p. 134).

i) Sustentabilidade financeira

A questão financeira é importante, dentre outras razões, para aumentar a autonomia da entidade que irá gerir o turismo no circuito turístico, reduzindo sua dependência do setor público embora não seja possível (nem desejável) eliminá-la completamente.

Tavares et al. (2010) menciona cinco fontes possíveis para a sustentabilidade financeira da entidade gestora de um circuito, a saber: a) cobrança de mensalidade dos membros do circuito; b) taxa de turismo, distinta daquela cobrada tradicionalmente pelo setor público; c) adopção de um "selo de envolvimento com o turismo"; d) patrocínios e marketing institucional; e) repasse das secretarias de turismo de cada município.

Em princípio, algumas dessas fontes são mutuamente excludentes, já que a cobrança de mensalidades dos membros pode ser realizada pelo próprio repasse de recursos das secretarias de turismo de cada município, caso os membros sejam apenas municípios e não empresas do setor privado. 
Uma ideia aparentemente pouco utilizada é a implantação de um selo que identifique a participação direta da empresa - de bens ou serviços - com o turismo local pode não somente contribuir para a arrecadação de recursos financeiros como também para mitigar o problema do free-rider, pois, neste caso, sinaliza ao turista quem contribui para o turismo na região.

O "selo de envolvimento com o turismo", emitido pela associação gestora, pode ter uma contrapartida por meio de recursos financeiros, apoio administrativo e pessoal. A obtenção deste selo também estaria vinculada ao cumprimento de uma série de ações a serem tomadas pelos estabelecimentos em prol da qualidade do atendimento e da satisfação do turista.

Gomes et al. (2008) afirmam que a forma mais usada no Estado de Minas Gerais seria a cobrança de mensalidades dos municípios integrantes do circuito. Porém, em caso de inadimplência, seria muito desgastante desfiliar o município do circuito, o que pode resultar em comportamento oportunista. Outra possibilidade é a de vincular a taxa de turismo (room tax) ao circuito turístico por via legal, de tal forma que uma parcela desses recursos seja transferida para a instituição.

Em Minas Gerais, tornou-se uma fonte de receita para os circuitos turísticos via Decreto-Lei 45.503, de 18/06/2010, o Imposto sobre a Circulação de Mercadorias e Serviços (ICMS) Turístico - uma parcela do ICMS que é repassada aos municípios com base em critérios relacionados à atividade turística.

Outra fonte de recursos para a entidade gestora seria a realização de eventos e a busca de patrocínios de empresas localizadas no próprio circuito turístico (Fernandes, 2006). Ressaltase, por fim, que cada circuito apresenta suas particularidades e que, nesse caso, é recomendável que se faça uma avaliação quanto às possibilidades de obtenção de recursos financeiros que possam viabilizar a estrutura e os projetos da associação gestora do mesmo, o que pode ser feito, inclusive, por empresas especializadas no setor turístico e, mais especificamente, em planeamento e marketing de destinos.

Entretanto, embora existam várias opções de obtenção de recursos, a situação dos circuitos em Minas Gerais em termos financeiros não parece satisfatória, pois, segundo Silva et al. (2011, p.11), em pesquisa realizada com 11 gestores de circuitos mineiros, "a dificuldade de sustentabilidade financeira dos circuitos, que se dá em sua maioria por meio do pagamento de mensalidades das prefeituras, tem representado um grande problema para os circuitos, visto que muitos municípios não conseguem se manter adimplentes. 


\section{Metodologia}

Quanto à natureza dessa pesquisa, a mesma é do tipo aplicada, visto que seu objetivo principal "é gerar conhecimentos para aplicação prática, dirigidos à solução de problemas específicos" (p. 35, - no caso, como formar circuitos turísticos.

Quanto aos objetivos e aos procedimentos, a pesquisa relacionada a esse artigo é do tipo exploratória e bibliográfica, dado que ela permitirá conhecer melhor a questão dos circuitos turísticos a partir das experiências realizadas em Minas Gerais por meio de levantamento bibliográfico desta temática usando diversos trabalhos publicados nos principais periódicos nacionais e internacionais (Gonçalves, 2003; Bolson, 2004; Santos, 2004; Teixeira et al, 2006; Gomes et al, 2006; Oliveira, 2006; Castro, 2007; Oliveira, 2007; Brida et al, 2008; Domingos e Ribeiro, 2008; Emmendoerfer, 2008; Gomes et al, 2008; Oliveira, 2008; Bercial e Timón, 2009; González e Mendieta, 2009; Araújo, 2009; Tavares e Vieira Junior, 2010; Tavares et al., 2011; Oliveira et al., 2013).

Uma vez realizado o levantamento bibliográfico, esse artigo passa a construção da proposta para a formação de circuitos turísticos, a saber, Etapa I - Planejamento; Etapa II Implementação e Etapa III - Monitoramento, conforme descrita a seguir.

\subsection{Proposta de formação de circuitos turísticos}

A proposta para a formação de circuitos turísticos compreende de 3 (três) etapas, a saber: I) Planejamento; II) Implementação; III) Monitoramento. Cada uma delas é composta por diversas ações, recomendações e indicações dos responsáveis pelas mesmas em termos de execução e verificação (checagem), baseadas principalmente nos elementos formadores de um circuito turístico - conforme mencionado anteriormente. As etapas são descritas no apêndice I.

A etapa I é composta por uma série de ações que visam a preparação das condições necessárias à execução do projeto de formação do circuito turístico. Como a participação deve ser ampla num processo como este, é preciso convocar todos os envolvidos com o turismo na região em questão com o intuito de discutir a realidade do setor, tendo em vista o primeiro elemento formador de circuitos turísticos - o número de municípios participantes.

Tal concepção encontra-se respaldo em (OLIVEIRA, 2010, p.3), segundo o qual "se o desenvolvimento local se faz através da participação, do comprometimento de atores sociais imbuídos do objetivo da construção coletiva, o planejamento turístico e por sua vez, as políticas 
públicas de turismo são permeados pelos mesmos comportamentos". Na oportunidade, todos devem apresentar os pontos fortes e fracos, as dificuldades principais e uma breve apresentação acerca dos principais atrativos de seus municípios.

Nesse encontro ou no próximo, deve ser verificada a possibilidade de organizar a gestão do turismo sob a forma de circuito turístico. Concomitantemente, pode ser encaminhado ao governo um posicionamento formal acerca de sua intenção, visando obter seu posicionamento em relação a formação do circuito.

A partir daí, os representantes dos municípios (ou de qualquer outra forma de divisão territorial) podem ter o auxílio do poder público (se esse se dispuser a isto formalmente) e decidir a forma pela qual será constituída a entidade gestora do circuito, passo fundamental para que a diretoria seja eleita, após, é claro, da elaboração e registro de seu Estatuto. Segundo Emmendoerfer et al. (2007, p.11), em Minas Gerais "alguns circuitos optaram por associações, outros por organizações não-governamentais, agências de desenvolvimento regionais e até mesmo OSCIP — Organização da Sociedade Civil de Interesse Público".

Oficialmente registrada, e entidade deve comunicar o fato (se sua formação não tiver sido induzida pelo governo) aos órgãos públicos responsáveis pelo turismo em todas as instâncias. Nesse ponto, que é a fase final da etapa I, a entidade gestora deverá agendar reuniões para elaborar os planos e projetos de trabalho a serem desenvolvidos, ou seja, um planeamento com ações de curto, médio e longo prazo, privilegiando sempre participação de todos os envolvidos com o turismo - direta e indiretamente - e também a comunidade, em dissonância com Oliveira et al. (2013, p.3), os quais afirmam que, uma vez "admitindo-se a gestão participativa de um conjunto de diferentes atores sociais locais no planejamento turístico, espera-se estruturar o desenvolvimento da comunidade receptora da atividade turística fundamentada num processo de organização pela e para a comunidade".

Na etapa II, de implementação do circuito turístico, são relacionadas diversas ações necessárias para o desenvolvimento do circuito, todas elas condizentes com o segundo elemento formador de circuitos, a saber, a tipologia do turismo. Embora já tenha sido descrito de forma oral e breve na etapa I, os atrativos turísticos e os equipamentos disponíveis no circuito deverão ser oficialmente inventariados, condição essencial para uma série de novas ações, tais como a elaboração de itinerários, roteiros turísticos, mapas, a identificação de locais que necessitam ser apoiados de infraestrutura (em atenção especial às condições de acesso e à instalação de um 
centro de informações turísticas) e suas restrições espaciais. Essa última é condição necessária - mas não suficiente - para diagnosticar o potencial turístico do circuito.

Em relação às necessidades de infraestrutura, a entidade gestora deve enviar aos órgãos públicos responsáveis uma petição solicitando que as mesmas sejam atendidas, até porque, em geral, melhorias em vias acesso, sinalização, segurança, iluminação, dentre outras, contribuem para o bem-estar da população. Essa questão refere-se ao elemento formador de um circuito, a saber, as condições de acesso e sinalização turística.

Em seguida, uma vez estabelecido o número de municípios participantes e a tipologia do turismo, passa-se à definição da imagem/identidade, a qual será usada interna e comercialmente. Os dois próximos passos consistem na escolha da denominação do circuito turístico - nome pelo qual será chamado - e qual será o município-polo, que deve ter sua posição em destaque em todos os materiais de apoio e de cunho comercial - ambos os passos pertencentes aos elementos formadores de um circuito.

No momento em que se elaboram os materiais e se inicia a divulgação do circuito - material de apoio e divulgação - é preciso estabelecer uma rede de empresas do trade baseada em atrativos e eventos para que, antes de viajar ao circuito ou quando lá estiver, o turista tenha facilidade em identifica-los e escolher de acordo com seu interesse. Para isso, deve-se discutir e planejar a implementação do Centro de Informações Turísticas (CIT), um dos elementos formadores de um circuito turístico.

O término dessa etapa implica em implementar os planos e projetos relacionados na etapa I, o qual deve incluir meios para que a entidade gestora seja auto sustentável financeiramente, diminuindo ou eliminando a dependência do setor público.

Por fim, a etapa III é de monitoramento, a qual muitas vezes é relativamente ignorada e pode significar a "salvação" ou a "consolidação" de um circuito turístico. Monitorar implica em avaliar, periodicamente, o resultado das ações antes implementadas, tanto do ponto de vista da oferta, da demanda e da população local. Embora não haja uma regra, recomenda-se que a avaliação seja anual, evitando as distorções da sazonalidade.

Internamente, pode ser avaliada a realidade das empresas do trade turístico no que se refere ao faturamento, lucro, recursos humanos, etc. bem como a visão da população local, além da relação com o setor público, principalmente em relação às parcerias, apoio e a variáveis tais 
como condições de acesso, sinalização turística e o estado dos equipamentos turísticos do circuito. Ressalta-se atualizar o inventário turístico periodicamente, se necessário.

Externamente, o perfil da demanda no circuito turístico deve ser levantado de forma periódica - variáveis sociais e econômicas, procedência, número de turistas recebidos, o tempo médio de estadia, renda média do turista e o volume de gastos realizados. Essas informações são muito úteis para a entidade gestora e para os membros do trade turístico, principalmente como um balizador para a realização de inovações.

Além de outros produtos decorrentes dessas informações, é possível determinar a área de influência do circuito por meio da análise de procedência, bem como verificar se as expetativas dos turistas foram atendidas, se pretendem voltar ou não, bem como as reclamações e elogios que porventura existiam.

Por fim, embora seja uma proposta com etapas e ações sucessivas, sua flexibilidade se mantém em virtude, principalmente, do estágio em que se encontra o turismo na região, da realidade financeira e disponibilidade de pessoal existente. De qualquer forma, pode servir de orientação para aqueles que desejarem fazer do turismo uma das alternativas para o crescimento econômico da sua região e de melhoria do bem-estar da população por meio de uma gestão diferenciada do espaço turístico.

\section{Considerações Finais}

Este artigo teve por objetivo desenvolver uma proposta para a criação de circuitos turísticos desde a sua implementação até à etapa de monitoramento, com linguagem clara e acessível para agentes do setor público e/ou privado.

A criação de circuitos turísticos é importante para o desenvolvimento dessa atividade visto que, muitas vezes, municípios polos com um atrativo exponencial pode "absorver" toda a atenção do turista e não colaborar com o crescimento de municípios no seu entorno, que também possuem atrativos merecedores de serem visitados. Portanto, percebe-se a proximidade do conceito de circuitos turísticos adotado nesse artigo com o de cluster turístico, definido de forma precisa por Beni (2003).

As experiências relacionadas à criação e certificação de circuitos turísticos ocorridas em Minas Gerais, desenvolvidas inicialmente pela SETUR-MG e mencionadas anteriormente, mostraram 
aspectos muito positivos para o turismo no Estado, principalmente naquelas regiões onde essa atividade já possuía um nível satisfatório de operacionalidade e de reputação.

As etapas e os elementos da proposta de formação dos circuitos, outrora descritas, contemplaram todas as funções da administração, a saber, o planejamento, a organização, a decisão e o controle.

A criação desta proposta é importante por pelo menos três razões: a primeira é que existem muitas definições para circuitos turísticos, embora haja uma ideia comum a todos que remete aos modelos de multidestinação; a segunda é porque os circuitos turísticos são importantes para descentralizar a gestão do turismo, pois permite que esta seja feita por agentes ou instituições que conheçam a realidade local/regional de forma mais profunda e a terceira porque as regiões turísticas, independente da sua forma de gestão, necessitam realizar mais esforços no sentido de coletar informações de seus turistas.

Essa proposta de formação dos circuitos turísticos deve ser testada em alguma região turística, sendo essa a principal sugestão de pesquisa a partir desse artigo.

\section{Referências}

ALBAGLI, S.; BRITO, J. Glossário de arranjos e sistemas produtivos e inovativos locais. Redes de pesquisa em sistemas produtivos e inovativos locais. Rio de Janeiro, 2003.

AMATO NETO, J. Redes de cooperação produtiva: antecedentes, panorama atual e contribuições para uma política industrial. Tese (Livre-docência). Universidade de São Paulo, 236f, 1999.

ANDRIGHI, F. F.; HOFFMANN, V. E. Redes e cooperação na destinação turística de Urubici/SC. Revista Turismo em Análise, São Paulo, v. 21, n. 1, p. 1-16, 2010.

ANDRADE, E. B. A oferta turística: uma abordagem mercadológica. Turismo - Visão e Ação - v.1 - n.2 - p.79-87 out-1998/mar-1999.

ARAÚJO, A. S. (2009). O ciclo de vida do fenômeno turístico em São Lourenço (MG): de estância hidromineral a destino de lazer e bem-estar. Dissertação (Mestrado em Geografia), Universidade Federal de Minas Gerais.

BENI, M. C. Globalização do turismo: megatendências do setor e a realidade brasileira. 1. ed. São Paulo: Aleph, 2003.

BERCIAL, R. A.; TIMON, D. A. B. Nuevas Tendências em el Desarrollo de Destinos Turísticos: Marcos Conceptuales Y Operativos para sú Planificacion y Gestión. Cuadernos de Turismo, v.15, p. 2743, 2009.

BOLSON, J. H. G. Circuitos Turísticos de Minas Gerais - Modelo de Regionalização - Ago/04. Disponível en: www.revistaturismo.cidadeinternet.com.br?artigos/minasgerais.html. Acesso em 12 abr. 2012. 
BRIDA, J. G.; LANZILOTTA, B.; BIBIANA; R.; WINSTON, A. Turismo y crecimiento econômico: El caso de Uruguay. PASOS. Revista de Turismo y Patrimonio Cultural, El Sauzal, Tenerife, v.6, n.3, p. 481-492, 2008.

BRITTO, J. Caraterísticas Estruturais dos Clusters Industriais na Economia Brasileira. Projeto de Pesquisa: Arranjos e Sistemas Produtivos Locais e as Novas Políticas de Desenvolvimento Industrial e Tecnológico/MT/OEA/CNDT/IEA. (Relatório Final)" Instituto de Economia/UFRJ. Rio de Janeiro, 2000 .

CARNEIRO, J. B.; FONTES, N. D. Turismo e eventos: instrumento de promoção e estratégia de marketing. Revista Turismo em Análise, Brasil, v. 8, n. 1, p. 65-74, mai. 1997.

CARVALHO, P. O turismo nas estratégias de desenvolvimento do mundo rural português: complemento ou alternativa?" In: Cruz, F. (org.). Atas do IV Congresso Internacional de Investigação e Desenvolvimento Sócio-Cultural, Póvoa de Varzim, AGIR, 1745-1768, 2007.

CASSIOLATO, J. E.; SZAPIRO, M. Uma caracterização de arranjos produtivos locais de micro e pequenas empresas. In: LASTRES, H. M. M.; CASSIOLATO, J. E.; MACIEL, M. L. Pequena Empresa: cooperação e desenvolvimento local. Rio de Janeiro, Relume Dumará, p. 35-50, 2003.

CASTRO, L. D. Análise sócio-econômica de demanda turística nas cidades que compóem o circuito mineiro das Águas. Dissertação de Mestrado em Turismo e Meio Ambiente, Mestrado em Turismo e Meio Ambiente, Centro Universitário UNA, Belo Horizonte, 2007.

CRASE, L. and JACKSON, J. Assessing the effects of information asymmetry in tourism destinations. Tourism Economics, v. 6, n.4, 321-334, 2000.

CUNHA, S. K.; CUNHA, J. C. Competitividade e sustentabilidade de um cluster de turismo: uma proposta de modelo sistêmico de medida do impacto do turismo no desenvolvimento local. Rev. adm. contemp. [online]. v.9, n.2, 2005.

CUNHA, M. O. A.; FERREIRA, M. A. T. A comunicação das organizações no processo de construção da imagem turística de Belo Horizonte. In: Atas do V Seminário da Associação Nacional de PósGraduação em Turismo. Belo Horizonte/MG, 25 e 26 de agosto, 2008.

DE LUCCA FILHO, V. Um estudo dos fluxos de informações em centros de informações turísticas no Estado de Santa Catarina: O Programa Portais do Lazer. Dissertação (Mestrado em Ciência da Informação) - Universidade Federal de Santa Catarina, 2005.

DINIZ, A. M. A.; VERSIANI, L. B. A demanda doméstica e internacional do produto turístico Ouro Preto e seus limites temporais e espaciais. Turismo - Visão e Ação, v. 8, n.1, p. 91-104, 2006.

MINISTÉRIO DO TURISMO. Guia Brasileiro de Sinalização Turística. EMBRATUR; IPHAN; DENATRAN. Brasília-DF, 2001.

EMMENDOERFER, M. L.; BUENO SILVA, L. F. T.; FONSECA, P. C. A formação dos circuitos turísticos mineiros: uma política pública descentralizada e democratizante?moni Revista Acadêmica Observatório de Inovação do Turismo, v.2, n. 4, p. 1-18, 2007.

EMMENDOERFER, M. L.; SILVA, F. C.; LIMA, A. A. T. F. Evidências de Inovação Social na Gestão Pública do Turismo em Minas Gerais - Brasil: O Modelo de Circuitos Turísticos em Análise" Passos El Sauzal, v. 9, n.2, p. 397-410, 2011.

FERREIRA, P. N. Programa de Recuperação de Aldeias Históricas de Portugal: um Balanço. Dissertação de Mestrado Integrado em Arquitetura de Coimbra, Junho, 2011.

GOHR, C. F.; SANTOS, L. C.; VEIGA, M. F. A informação como um elemento chave para a qualidade do produto turístico: uma análise dos postos de informações turísticas do município de Florianópolis/SC. Perspectivas em Ciência da Informação, v. 14, n. 2, May-August, p.169-186 2009. 
GOMES, B. M. A.; SILVA, V. J.; NETO, E. Q. A ação coletiva em regiões turísticas: um estudo dos circuitos turísticos de Minas Gerais. Turismo - Visão e ação, v.8, p.2, p.332-330 maio/agosto, 2006.

GOMES, B. M. A.; SILVA, V. J.; SANTOS, A. C. Políticas Públicas de Turismo: uma Análise dos Circuitos Turísticos de Minas Gerais sob a Concepção de Cluster. Turismo em Análise, v.19, n.2, p.201$220,2008$.

GONZÁLEZ, R. C.; MENDIETA, M. D. (2009) Reflexiones sobre la Conceptualización de la Competitividad de Destinos Turísticos. Cuadernos de Turismo, 23, p. 111-128.

GUTIÉRREZ, C. E.; BORDAS, E. La competitividad de los destinos turísticos en mercados lejanos. ln: Anais do Congresso da AIEST, Buenos Aires, p. 103-193, 1993.

HWANG, Y-H.; FESENMAIER, D. R. Unplanned tourist attraction visits by travelers. Tourism Geographies, v.13, n.3, p.398-416, 2011.

HWANG, Y-H.; LI, Z. The influence of information provided at tourist information centers on travel decisions: Comparison between purposive and spontaneous stoppers. Asia Pacific Journal of Tourism Research, v.13, n.1, p.1-18, 2008.

IVARS, J. A. Planificación Turística de los Espacios regionales en España. 1. ed. Madrid: Síntesis, cap. 1, p. 25-26, 2004.

LEISEN, B. Image segmentation: the case of a tourism destination. Journal of Services Marketing, v.15, n.1, p.49-66, 2001.

MARTINS, H. S.; SICSU, A. B. Modelo de identificação de Clusters Turísticos. In: XII SIMPEP Bauru, SP, Brasil, 07 a 09 de novembro, 2005.

MEI, B.; SILVA, K. O.; ENDO, P. Centrais de Informações Turísticas da cidade de São Paulo: uma análise crítica do atendimento. Revista Eletrônica de Turismo Cultural, Número especial, p.1-17, 2010.

MICHELON, A. O Papel da Comunicação Inter-Organizacional no Desenvolvimento do Cluster Turístico da Serra Gaúcha. Caxias do Sul: Universidade de Caxias do Sul, 2003.

MILHEIRO, E.; DINIZ, G.; CORREIA, E. O papel do Observatório do Turismo na operacionalização de competências da Entidade Regional de Turismo do Alentejo. Disponível em http://comum.rcaap.pt/bitstream/123456789/2053/1/O\%20papel\%20do\%20Observat\%C3\%B3rio.

Acesso em 19 abr. 2010.

Metodologia de Inventariação de Recursos Turísticos para o Território do Alentejo. In: $17^{\circ}$ Congresso da Associação Portuguesa de Desenvolvimento Regional (APDR), Bragança, 2011.

MINAS GERAIS. Decreto n. 43.321 de 08 de maio de 2003. Dispõe sobre o reconhecimento dos Circuitos Turísticos e dá outras providências. Disponível em:

http://www.revistaturismo.com.br/artigos/minasgerais2.html>. Acesso em: 15 mai. 2011.

NETO, I. O.; TEIXEIRA, L. A. A.; SILVA, J. T. A imagem de Belo Horizonte: um estudo para sua identificação por meio da técnica de configuração de imagem de produto. Revista Acadêmica Observatório de Inovação do Turismo, Rio de Janeiro, v.3, n.2, p.1-23, 2008.

NOGUEIRA, F. V. Análise da sinalização turística nos atrativos turísticas da cidade de Dourados-MS. Revista Iberoamericana de Turismo - RITUR, v.2, n.2, p. 40-45, 2012.

OLIVEIRA, J. M. S. R.; Santos, A. C. O turismo como alternativa para o desenvolvimento da competitividade: uma análise da "rota dos tropeiros" no Oeste de Minas Gerais. FACEF Pesquisa, v.9, n.3, p. 332-342, 2006.

OLIVEIRA, F. F. Circuitos Turísticos de Minas Gerais: espaços de diálogo, educação e cidadania. In: VII SEGeT - Simpósio de Excelência em Gestão e Tecnologia - 2010. 
OLIVEIRA, F. F.; SANTIAGO, A. M.; FUCHS, L. (2013). O planejamento turístico participativo na gestão do Circuito Turístico Trilha dos Inconfidentes/MG. Revista NAU Social, v.4, n.6, p. 100-119.

RAMOS, B. A. (2006) Políticas públicas no turismo: o caso de Minas Gerais. Disponível em <http://www.etur.com.br/conteudocompleto.asp?idconteudo=9359>. Acesso em: 15 jun. 2012.

SANTOS, A. A. A importância do circuito turístico para o fomento da economia e da preservação ambiental - Caso São Roque de Minas. Dissertação de Mestrado em Administração. Universidade Federal de Lavras, Lavras, 2004.

SANTOS, G. E. O.; RAMOS, V.; REY-MAQUEIRA, J. Single and multiple destination tourism trips in Brazil: understanding tourist choices. Seminário Anual da Associação Nacional de Pesquisa e PósGraduação em Turismo; In: VII Seminário da Associação Brasileira de Pesquisa e Pós-Graduação em Turismo, agosto, 2010.

SANTOS, V. M. Notas Conceituais sobre Abordagem de Clusters Produtivos. Revista Espaço Acadêmico. Ano III, 27, Agosto, 2003.

SETUR. Secretaria de Turismo do Estado de Minas Gerais. (2015). Disponível em http://www.turismo.mg.gov.br/. Acesso em: 07 set. 2015.

SILVA, F. G. S.; MELO, R. S. A contribuição da sinalização turística para o desenvolvimento turístico da cidade de Parnaíba (PI, Brasil). Revista Brasileira de Pesquisa em Turismo, v. 6, n.2, p. 129-146, mai./ago. 2012.

SILVA, J. A. S. Turismo, Crescimento e Desenvolvimento: uma análise urbano-regional baseada em cluster. Tese de Doutorado em Comunicação Social. Universidade de São Paulo - USP, São Paulo, 2004.

SILVA, F.C.; CARVALHO LIMA, A. A. T. F.; FERREIRA, T. R.; ALBINO, A. A.; SILVA, M. A.; OLIVEIRA, R. S. Avaliação da Política de Circuitos Turísticos de Minas Gerais na Percepção de Agentes Estratégicos: Principais Resultados, Dificuldades e Perspectivas. In: XXXV Encontro da ANPAD, Rio de Janeiro, 4-7 de setembro, 2011.

SILVA, F. C.; LIMA, A. A. T. F. C.; TEIXEIRA, M. A. A cooperação intermunicipal nos circuitos turísticos de Minas Gerais. Revista Acadêmica Observatório de Inovação do Turismo, v.2, n.1, Rio de Janeiro, abril, 2012.

TAVARES, J. M.; JONAS, A. V. J; MARIANO, J. Circuito turístico Montanhas Mágicas da Mantiqueira (Minas Gerais - Brasil): uma análise. Pasos (El Sauzal), v. 9, p. 661-670, 2011.

TAVARES, J. M.; VIEIRA JUNIOR, J. A. Circuito Turístico Terras Altas da Mantiqueira: uma análise situacional a partir da percepção dos agentes ligados ao turismo. Revista Acadêmica Observatório de Inovação do Turismo, v.5, p.1-18, 2010.

TAVARES, J. M.; VIEIRA JUNIOR, J. A. V.; QUEIROZ, S. F. Circuitos turísticos de Minas Gerais: uma análise a partir de ferramentas de geoprocessamento. Turismo em Análise, v.21, n.1, p. 25-47, 2010.

TEIXEIRA, A.; VICENTIM, F. M.; AGUIAR, V. Circuitos turísticos e sua importância para o turismo no espaço rural brasileiro. Atas do Congresso Latino Americano de Sociologia Rural, Equador. Anais... Quito, 2006.

TIERNEY, P. The influence of state traveler information centers on tourist length of stay and expenditures. Journal of Travel Research, v.31, n.3, p.28-32, 1993.

TOLEDO, G. L.; SILVA, A. C. A. Estratégias competitivas e cooperativas em clusters turísticos - um diagnóstico da Região dos Lagos. Atas do VII SEMEAD - Seminários em Administração, São Paulo, (2004).

TYREL, T. J.; JOHNSTON, R. J. Assessing expenditure changes related to welcome center visits. Journal of Travel Research, v.42, August, p.100-106, 2003. 
VEIGA, J. E. Cidades imaginárias: o Brasil é menos urbano do que se calcula. Campinas: Autores Associados, 2002.

VENTURA, M. S. G. Património e Turismo em áreas de baixas densidades: o caso das aldeias do Pessegueiro e do Esquio" Dissertação de Mestrado Integrado em Arquitetura de Coimbra, Junho, 2010.

VIANNA, S. L. G.; HOFFMANN, V. E. Classificação dos municípios catarinenses com base nos indicadores para a formação de um cluster de turismo cultural. Caderno Virtual de Turismo, v.9, n.2, 2009.

Recebido em: 10/04/2015 (1 ${ }^{\text {a }}$ versão) 16/10/2015 (última versão)

Aprovado em: 20/10/2010 


\section{Apêndice I}

\section{Proposta para a Formação de Circuitos Turísticos - 1르 Etapa - Planejamento}

A $1^{\text {a }}$ etapa, de planejamento do circuito turístico, é composta por 9 (nove) ações relativas à preparação necessária para a implementação das próximas etapas, a saber:

1a ação: Convocar todos os agentes envolvidos na cadeia produtiva do turismo - hospedagem, restaurantes, lazer, transportes, receptivos, locadoras de automóveis, dentre outros - localizados nos municípios integrantes da região político-administrativa oficial para a apresentação informal do projeto e agendamento da $1^{\text {a }}$ reunião.

Responsabilidade: Qualquer agente envolvido com a atividade turística, independente do segmento.

Local: Área que não exija pagamento de entrada aos convidados.

Necessário espaço de confraternização.

Meio: Media tradicional, associações patronais, sindicatos, etc.

$2^{2}$ Ação: Discutir a realidade do setor de turismo nos municípios que demonstraram interesse oficial pelo projeto. Nessa reunião, cada representante de município apresentará a situação da sua região.

Responsabilidade: Todos os municípios que se interessaram oficialmente no projeto.

Local: Idem ação 1.

Pauta: Aspectos quantitativos e qualitativos do turismo em cada município - pontos fortes e fracos, breve descrição dos atrativos turísticos e do panorama político municipal.

3a Ação: Avaliar o posicionamento oficial do governo - em todas as suas esferas possíveis - em relação ao apoio político, administrativo, financeiro e técnico ao circuito turístico.

Responsabilidade: Idem ação 2.

Local: Idem ação 1.

Pauta: Leitura e discussão de documento oficial enviado pelo governo (em todas as suas esferas).

4a Ação: Definir a forma de organização do circuito turístico institucionalmente e fazer as prévias para a elaboração de seu Estatuto.

Pauta: Forma de organização do circuito turístico (associação, organização não-governamental, organização privada de interesse público, dentre outras) e iniciativas para a elaboração do Estatuto.

Responsabilidade: Idem ação 1 .

Local: Idem ação 1.

5 Ação: Elaborar Estatuto de funcionamento da entidade gestora.

Pauta: Elaboração do Estatuto, com cargos existentes, bem como direitos e deveres, forma de eleição, parâmetros para escolha de município polo, para filiação e desfiliação, dentre outras questões.

Responsabilidade: Idem ação 1, com auxílio de assessoria jurídica governamental ou privada.

Local: Idem ação 1.

6- Ação: Aprovar Estatuto e definir os candidatos à diretoria da entidade gestora.

Pauta: Leitura, discussão e aprovação do Estatuto da entidade gestora.

Apresentação dos candidatos à diretoria.

Responsabilidade: Idem ação 1.

Local: Idem ação 1.

$7^{a}$ Ação: Eleger e empossar a diretoria da entidade gestora.

Responsabilidade: Definido pelo Estatuto na ação anterior.

Local: Que tenha condições para uma votação transparente e contagem dos resultados, além de espaço para confraternização.

8aㅗ Ação: Comunicar a organização de entidade gestora do turismo aos órgãos públicos responsáveis pelo turismo.

Responsabilidade: Definido pelo Estatuto na ação anterior.

Local: Sala própria da entidade gestora.

9aㅡㄹㅡ: Apresentar os projetos a serem desenvolvidos pela entidade gestora.

Pauta: Apresentação dos projetos e discussão com os agentes e com a sociedade.

Responsabilidade: Definido pelo Estatuto na ação anterior.

Local: Idem ação 1.

\section{Formação de Circuitos Turísticos - 2ª Etapa - Implementação}

A $2^{\mathrm{a}}$ etapa, de implementação do circuito turístico, é composta por 10 (dez) ações relativas à execução dos projetos apresentados na $1 \stackrel{\text { a }}{ }$ etapa, a saber:

1a Ação: Levantamento/diagnóstico dos atrativos turísticos do circuito, bem como dos equipamentos disponíveis.

Responsabilidade: A contratação deve ser feita pela entidade gestora e a execução pode ser feita por instituição de ensino (pública ou privada), empresa de consultoria ou pelo setor público (municipal ou estadual).

$2^{2}$ Ação: Realizar pesquisa de demanda turística em todo o circuito e apresentar os resultados da pesquisa ao trade turístico e demais interessados. 
Responsabilidade: Idem ação 1 desta etapa.

Local: idem ação 1 , na $1^{\text {a }}$ etapa.

3a Ação: Identificar e discutir os pontos fortes e fracos do turismo no circuito a partir da pesquisa de demanda turística, além da definição da sua imagem e de sua identidade visual.

Responsabilidade: Entidade gestora e demais interessados.

4ª Ação: Propor melhorias, de responsabilidade pública e/ou privada, por meio da identificação de produtos e serviços que podem vir a ser inseridos ou melhorados no circuito turístico.

Responsabilidade: Entidade gestora e trade turístico.

5a Ação: Fazer material de apoio e para comercialização do circuito, tais como, mapas, roteiros, folders, guias e site informativo e interativo.

Responsabilidade: idem $1^{\underline{a}}$ ação desta etapa. Pode ser contratado serviço de terceiros.

6ª Ação: Apresentar o material de apoio desenvolvido ao trade turístico e aos demais interessados e proceder a sua distribuição e divulgação.

Responsabilidade: Área de comunicação da entidade gestora.

Local: idem ação 1, na 1를 etapa.

Divulgação/Distribuição: Media em geral, escolas, associações, sindicatos, segmentos de transporte e alimentação, terminais de transporte de passageiros, CIT's, etc.

$7^{a}$ Ação: Equipar o circuito com um Centro de Informações Turísticas de responsabilidade da entidade gestora.

Responsabilidade: Entidade gestora.

Local: Preferencialmente no município polo.

$8^{a}$ Ação: Analisar os atrativos turísticos correlacionando-os com as informações prestadas pela pesquisa de demanda turística realizada, a fim de verificar eventuais necessidades de alteração ou implementação de pontos de apoio, mais informações, etc. Responsabilidade: Entidade gestora.

9a Ação: Elaborar uma rede de interação entre os municípios e agentes privados integrantes do circuito para a troca de informações e confecção de um calendário (semanal, preferencialmente) com atrações temporárias (festivais/eventos/shows, teatro, amostras, etc).

Responsabilidade: Entidade gestora em parceria com os integrantes do circuito. A execução poderá ficar a cargo de empresa especializada/instituição de ensino.

Divulgação: Media global, escolas, associações, sindicatos, etc.

10 Ação: Elaborar um calendário com reuniões, apresentações, audiências públicas, dentre outras formas de encontro, para se discutir o desenvolvimento do circuito turístico regional.

Responsabilidade: Área de comunicação da entidade gestora.

Local: idem ação 1 , na $1^{\text {a }}$ etapa.

Divulgação: Media em geral, escolas, associações, sindicatos, etc.

\section{Formação de Circuitos Turísticos - 3ª Etapa - Monitoramento}

A $3^{a}$ etapa, de monitoramento do circuito turístico, é composta por 2 ações ditas principais e relativas à observação dos resultados apresentados pelas $1^{\underline{a}}$ e $2^{\underline{a}}$ etapas anteriores, a saber:

1a Ação: Diagnosticar, anualmente, as condições do circuito turístico. Esta ação é composta por outras 6 ações, conforme descritas a seguir.

a) Avaliar as empresas do trade turístico em 5 (cinco) áreas, a saber: financeira (rentabilidade, lucratividade, crédito, etc), comercial (volume de vendas, formas de vendas, etc), recursos humanos (treinamento, necessidade de pessoal, etc) relação com o mercado (clientes, fornecedores, parcerias) e na relação com o governo.

b) Avaliar a opinião da população local em relação ao turismo em 4 (quatro) dimensões: impactos na cultura local, no trânsito, no meio ambiente, nos preços dos bens e serviços e no fornecimento de bens públicos (energia, segurança, etc).

c) Avaliar a relação entre a entidade gestora do circuito turístico e os órgãos públicos sob 3 (três) questões em particular: a) apoio político, técnico, administrativo e financeiro; b) realização de parceria; c) autonomia/ingerência, etc.

d) Avaliar as condições de acesso, a sinalização turística, a situação dos equipamentos turísticos e a necessidade de atualização do inventário turístico.

Responsabilidade: Entidade gestora.

$2^{a}$ Ação: Diagnosticar o perfil da demanda existente no circuito turístico. Esta ação é composta por quatro ações abaixo relacionadas.

a) Obter as informações sociais e económicas do turista.

b) Obter informações relativas ao número de turistas recebidos, o tempo médio de estadia, tipo de hospedagem e o volume de gastos realizados.

c) Determinar a área de influência do circuito por meio da análise de procedência.

d) Obter informações relativas às expetativas dos turistas - se atendidas ou não; se pretendem voltar ou não - reclamações e elogios.

Responsabilidade: Entidade gestora ou pela contratação de empresa ou instituição especializada. 